\title{
Editorial
}

Joseph A. Fisher MD FRCPC,

Chidambaram Ananthanarayan MD FRCPC. Gerald Edelist MD FRCPC

\section{Role of the laryngeal mask in airway management}

The laryngeal mask (LM) was introduced by Brain in $1983^{\prime}$ as an adjunct to airway management during anaesthesia. The device consists of a wide bore tube whose distal opening is surrounded by an oval inflatable cuff. The cuff is designed to make a seal around the patient's larynx and direct the inspired and expired gases through the tube.

The LM is prepared by aspirating all the air from the cuff and lubricating it thoroughly. After the patient is anaesthetized, the patient's head is extended, the mouth propped open, and the tube passed into the pharynx. The cuff is inflated and the LM is observed to "ride up" slightly. The LM is then connected to the anaesthesia circuit. Several unobstructed breaths confirm proper placement.

Initial reports expressed great enthusiasm for the use of the $\mathrm{LM}$ for a wide variety of procedures employing both controlled and spontaneous ventilation, as well as for the management of patients with difficult airways. As it becomes more widely used we anticipate more case reports, such as that by Nanji and Maltby ${ }^{2}$ in this issue of the Journal, of adverse outcomes related to its use. These reports should not discourage the use of the LM, rather they should alert us to establish reasonable guidelines so that it can be used to its best advantage.

We feel there are certain conditions for which the LM is clearly unsuitable.

I Residual intact upper airway reflexes. The device is rather bulky and cannot be inserted unless the jaw and pharynx are fully relaxed. Inadequately anaesthetized patients may gag, cough, vomit, develop laryngospasm and bite down on the tube. Constriction of the pharyngeal muscles may prevent proper placement of the cuff and lead to obstruction of the larynx. The LM, therefore, is not suitable for patients who cannot be paralysed or anaesthetized deeply enough for its insertion.

From the Department of Anaesthesia, Mount Sinai Hospital at the University of Toronto, 600 University Avenue, Toronto, Ontario, M5G IX5.

Accepted for publication 17th September, 1991.
2 Inability to extend the neck. It is difficult to advance the LM into the pharynx in some patients without extending their neck. Caution should be exercised in using the LM in patients with cervical spine pathology.

3 Risk of aspiration. The cuff on the LM does not protect the tracheo-bronchial tree from the contents of the gastro-intestinal tract. This risk has been discussed by a number of authorities including the inventor, and has been confirmed by the case presentation of Nanji and Maltby in this issue of the Journal.

4 Local pathology in the pharynx. The LM is generally unsuitable for patients with local pharyngeal pathology such as disruption of the mucosa, oedema, haematomas, parapharyngeal abscesses, and pharyngeal abscesses. We have noted on occasion (as have Maltby et $\mathrm{al}^{3} .^{3}$ ) that in some patients who appear otherwise normal, the mouth and oropharynx appear to be too small to accommodate the LM.

5 Laryngeal problems. The construction of the LM has no advantage in overcoming obstruction at the level of the larynx. Attempting to ventilate the lungs of a patient with laryngospasm through an LM may force air into the stomach and predispose the patient to regurgitation and aspiration.

6 Increased pulmonary inflation pressures. The LM is unsuitable in providing positive pressure ventilation for patients with low pulmonary compliance or high airway resistance. For example, the LM is unsuitable for cases such as laparoscopy, Caesarean section, or in patients with massive obesity, pulmonary oedema, and asthma.

7 Known difficult airway access. The LM (except in emergency situations as described below) is contraindicated in patients whose tracheas are known to be difficult to intubate and whose lungs are difficult to ventilate. It is not a substitute for tracheal intubation in this situation. The same principle applies to the patient who does not have a difficult airway, but will be positioned for surgery in a way that would create difficulties should intubation become necessary during the operation, e.g., the prone, lateral and jack-knife positions.

8 Use as an emergency airway. One has only to look at 
the list of cautions and contraindications above to note that the likely benefit of the LM as an emergency airway in the Emergency Department is limited. Patients in the emergency room are likely to be awake, uncooperative, unwilling to open their mouths, have intact gag reflexes, full stomachs and an inability to extend their necks. They may have an unstable neck, local pharyngeal pathology, be prone to laryngospasm or the trachea may be difficult to intubate. They may have diseases that manifest a decrease in chest compliance. More commonly patients receiving IPPV in the emergency ward are at increased risk of generating high airway pressures due to their coughing and struggling.

These notes of caution are meant to dampen some of the unrealistic expectations that resulted from the use of the LM in cases for which it was suited.

Certainly when used correctly the LM is a great advance over previous known methods.

1 Use in routine anaesthesia. In many situations the LM is a superior substitute for holding a face mask in a spontaneously breathing anaesthetized patient. This is particularly true when holding a face mask may encroach on the surgical field. For example in minor breast surgery, we find the LM an ideal alternative to using a face mask or intubating the trachea. The LM provides a better seal than a face mask if the facial contours are not suited to the mask or the patient has a heavy beard. The LM is suitable for a patient whose pharyngeal anatomy requires a nasopharyngeal or an oropharyngeal airway to maintain patency.

2 Use as an emergency airway. This would be suitable in the "flat" or paralysed patient whose trachea has not yet been intubated and whose lungs are difficult to ventilate with bag and mask.

3 Can't intubate - can't ventilate. In the scenario of inability to intubate or ventilate the patient after the induction of anaesthesia, the LM may be lifesaving. In most cases, this should be considered a temporising measure to support the patient until definitive measures can be taken.

There is no doubt that the LM is a well designed and effective device which has an unique role in airway management in general, and in anaesthesia in particular. Reports of adverse outcomes related to the use of the LM will influence the pattern of our practice. In order that this influence be appropriate, we must first judge whether these complications arose as a result of a short-coming in its design, or as the result of its inappropriate use.

\section{La vraie place du masque laryngé}

Développé par le Dr Brain, le masque laryngé (ML) a fait son apparition en $1983^{\prime}$ à titre d'accessoire servant au contrôle des voies respiratoires pendant l'anesthésie. Il est composé d'un tube de fort calibre dont l'extrémité distale est entourée d'une manchette gonflable qui, se moulant au pharynx, entoure le détroit laryngé, assurant une continuité entre le larynx, le tube et l'extérieur.

Avant l'insertion du ML, on lubrifie légèrement la face postérieure de sa manchette qui est complètement dégonflée. Une fois la tête du patient anesthésié en extension et la bouche ouverte (celle du patient) on glisse le ML dans le pharynx. On gonfle alors la manchette, ce qui fait légèrement sortir le tube. On branche ce dernier au circuit respiratoire et on s'assure que la respiration n'est pas obstruée.

Le masque laryngé a fait une entrée remarquée et on l'a rapidement mis a contribution de diverses façons, tant en ventilation spontanée que contrôlée ; il a aussi servi pour des cas à l'anatomie respiratoire anormale. Toutefois, la lune de miel arrive à son terme et plus on utilisera le masque laryngé, plus on pourra, à l'instar de Nanji et Maltby, ${ }^{2}$ faire l'expérience de certaines complications reliées à son usage qui devront, non pas décourager son emploi mais plutôt, mieux le baliser.

Nous croyons qu'il existe des contre-indications à l'usage du masque laryngé :

1 Persistance des réflexes des voies respiratoires supérieures. Le ML est relativement gros et son insertion requiert une relaxation complète de la mâchoire et du pharynx. Sans anesthésie adéquate, le patient peut avoir un haut-le-coeur, tousser, vomir, faire un laryngospasme ou mordre le tube. La constriction des muscles pharyngiens peut déplacer la manchette, obstruant le larynx. On ne devrait donc pas employer le ML chez les patients qu'on ne peut paralyser ou anesthésier assez profondément pour sa mise en place.

2 Extension cervicale impossible. Il est difficile de glisser le ML dans le pharynx d'un patient sans faire une extension de son cou. On devrait donc être particulièrement prudent si on utilise le ML chez un patient à la colonne cervicale anormale.

3 Risque d'aspiration. La manchette du ML n'isole pas complètement la trachée du contenu stomacal. Plusieurs auteurs, dont l'inventeur, ont souligné cette limite qui est illustrée dans l'article de Nanji et Maltby ${ }^{2}$ qu'on peut lire plus loin dans ce numéro. 
4 Pathologie pharyngée. Il est difficile d'employer le ML chez les patients qui ont de l'oedème ou une déchirure des muqueuses pharyngées, un hématome ou un abcès pharyngien ou parapharyngien. Nous avons aussi noté (tout comme Maltby et al. ${ }^{3}$ ) qu'à l'occasion, la bouche et l'oropharynx d'un patient par ailleurs normal semblent trop petits pour y introduire le masque laryngé.

5 Obstruction laryngée. Le masque laryngé ne peut pas vaincre une obstruction du larynx. L'obstination à ventiler avec un ML les poumons d'un patient en laryngospasme peut remplir d'air l'estomac, prédisposant ainsi à la régurgitation et à l'aspiration.

6 Pression de ventilation élevée. On serait mal avisé d'employer le ML en ventilation contrôlée chez des patients à faible compliance pulmonaire ou à résistance élevée des voies respiratoires. À titre d'exemple, on peut dire que les cas de laparoscopie et les césariennes de même que les patients qui sont très obèses, ont de l'asthme ou de l'oedème pulmonaire se prêtent mal à l'usage du masque laryngé.

7 Accès restreint aux voies respiratoires. Sauf en cas d'urgence, l'usage du ML est contre-indiqué chez les patients que l'on sait difficile à intuber et à ventiler. Pour ces cas là, le ML ne saurait être un substitut à l'intubation trachéale. Le même bémol s'applique aux cas ou la position employée durant l'intervention rendrait difficile l'intubation si elle devait s'avérer nécessaire : position ventrale, décubitus latéral.

8 À l'urgence. Avec les restrictions énoncées ci-haut, on voit bien le rôle limité que sera appelé à jouer le ML à l'urgence. Les patients de la salle d'urgence sont susceptibles d'être éveillés, combatifs, peu désireux de s'ouvrir la bouche en plus d'avoir intacts leurs réflexes pharyngés ; sans parler de leur estomac souvent plein et de leur cou à l'extension limitée. Leur colonne cervicale peut être instable et leur pharynx anormal, ils sont sujets au laryngospasme et s'avéreront peut être difficile à intuber. Leur compliance pulmonaire est possiblement réduite et de toute façon, les patients ventilés mécaniquement en salle d'urgence ont souvent des pressions d'insufflation élevées en raison de leur toux ou de leur combativité.

Voilà donc quelques mises en garde qui devraient juguler les attentes irréalistes que certains ont placé envers le masque laryngé. Cela ne devrait toutefois pas refroidir l'enthousiasme de ceux qui entendent s'en servir lorsque indiqué, là où il s'avère grandement supérieur aux autres méthodes connues.

1 Anesthésie de routine. Dans bien des cas, il est préférable d'utiliser un ML, plutôt que de tenir un masque sur le visage d'un patient qui respire spontanément, surtout si cette demière option devait gêner le chirurgien. À titre d'exemple, la chirurgie mineure du sein se prête très bien à l'usage d'un ML évitant ainsi l'intubation de la trachée. D'ailleurs, le ML offre une meilleure étanchéité qu'un masque facial qui s'adapte parfois mal à la forme du visage ou à la présence d'une barbe. II esı aussi utile pour les patients qui ont une anatomie pharyngée requérant autrement la présence d'une canule oro ou nasopharyngée lorsque ils sont inconscients.

2 En cas d'urgence. Le masque laryngé a sa place chez le patient profondément inconscient dont la trachée n'est pas encore intubée et dont les poumons sont difficiles à ventiler avec un masque facial.

3 Intubation et ventilation impossibles. S'il s'avère impossible d'intuber non plus que de ventiler un patient après l'induction de l'anesthésie, l'usage du masque laryngé saura peut être faire avorter le cauchemar. Il ne devrait probablement servir dans ce cas que de mesure temporaire en attendant d'apporter une solution plus définitive au problème.

Il ne fait aucun doute que le masque laryngé constitue un outil efficace et bien fait qui a sa place dans l'arsenal visant au contrôle des voies respiratoires de même qu'en anesthésie. Les quelques complications qui émailleront son usage devront être analysées avec soin afin de faire la part des responsabilités respectives du masque laryngé et de son utilisation afin de mieux les prendre en compte dans notre pratique.

\section{References}

1 Brain AlJ. The laryngeal mask - a new concept in airway management. Br J Anaesth 1983; 55: 801-5.

2 Nanji $G M$, Maltby $J R$. Vomiting and aspiration pneumonitis with the laryngeal mask airway. Can J Anacsth. This issue.

3 Maltby JR, Loken RG, Watson NC. The laryngeal mask airway: clinical appraisal in 250 patients. Can J Anaesth 1990; 37: 509-13. 